\title{
RICHARD JENKINS
}

\section{FÆLLESSPISNING MIDT I JYLLAND \\ NÅR DET DREJER SIG MERE OM SPISNING OG DRIKNING END OM MAD OG DRIKKE}

Palle Lauring sagde engang at „Danmark er en brugsforening“"1 - en bemærkning som både er dybsindig og sammensat, og så banal at det nærmer sig det selvindlysende. I denne artikel vil jeg se nærmere på nogle af dens implikationer ved at benytte mig af etnografisk materiale om spisning og drikning i Danmark. ${ }^{2}$ Men før vi sætter os ned for at tage fat på den etnografiske hovedret, bør der indtages en teoretisk hors d'oeuvre (da en akademisk artikel jo lige så vel som et måltid også bør besidde en konventionel struktur).

\section{Antropologiske og sociologiske tilgange til mad og drikke}

Georg Simmel havde næsten ret - der kan vel være en eller to ting mere - da han sagde at behovet for mad og drikke er det mennesker har allermest til fælles (1950:33). Måske endnu vigtigere her er det at mad og drikke, og spise- og drikkeforløb, kan være det antropologer og sociologer har allermest til fælles, ikke blot indbyrdes, men, mere afg $\varnothing-$ rende, med de folk de studerer. Med deltagelse-observations-feltarbejdet som grundmetode er dette noget overmåde selvfølgeligt for antropologer.

Men hvis dette var hele sagen, så ville madens og drikkens antropologi og sociologi blive til randbemærkninger, anbragt som fodnoter eller i beskrivelser af forskningserfaringer (ej at forglemme kogebøger (Kuper 1977)). Det er det da heller ikke, og at anerkendte teoretikere har bidraget til denne litteratur, peger på noget ganske andet som er mere i overensstemmelse med både vores egen indfødte sunde fornuft og med vores, ideelt set mere distancerede, antropologiske viden. Mad og drikke er afgørende for menneskelivet, ikke blot som - hvis det er det rette ord - næring, men også som bærere af mening og betydning. Mad og drikke retter vores opmærksomhed mod kernetemaer i kulturen og den kollektive identifikation. Den righoldige ,naturlige“ overflod af potentielt spiselige substanser omformes af enhver kulturtradition til en arbitrær og distinktiv menu. Men skønt mad og drikke, som kultur- og identitetsdimensioner, derfor nødvendigvis er fuldstændigt billedlige, er de jo ikke indbildninger. Mad og drikke holder os i live - med alle de betydninger den sætning rummer - og intet kan være mere virkeligt end det.

Bortset fra henvisninger til mad og drikke i den udførlige beskrivelse af andre emner - trobriandernes yams osv. - er der tre grundlæggende, og overlappende, analytiske til- 
gange til mad og drikke. Den første, som er af begrænset relevans i vores sammenhæng, begynder med ernæringens kendsgerninger og nødvendigheder (se de Garine 1994 for en oversigt). Den anden, den strukturalistiske tilgang, behandler mad og drikke som noget der belyser centrale kulturelle klassifikationsprincipper hvilket atter afdækker menneskekulturens generelle strukturelle logik(ker). Her er sproget modellen, eller metaforen, for kultur som man tilnærmer sig som en kode der kan forstås og som et objekt egnet for kvasigrammatisk analyse. Det klassiske værk i den strukturalistiske analyse af mad og drikke, hvor omdrejningspunket er elementære oppositioner som kultur/natur, menneskelig/ikke-menneskelig, spiselig/uspiselig osv., er Lévi-Strauss' berømte analyse af „det rå og det tilberedte“ (1970).

En konsekvent strukturalistisk tilgang til vores emne findes i Mary Douglas' værker. Tonen slås allerede an i en artikel, der første gang blev udgivet i 1972 (Douglas 1975: 249-75), hvor hendes målsætning er at „,dechifrere“ et måltid, at knække den eller de kulturelle koder som maden udtrykker. At mad indeholder og bærer en meddelelse fremgår udtrykkeligt af titlen på et efterfølgende essay, „Mad som et kommunikationssystem" (Douglas 1982:82-124). Det blev skrevet som en rapport til det britiske sundhedsministerium og behandler de forhindringer for en ,rationel“ ernæring som skyldes madens symbolske og klassifikatoriske dimensioner. „Føde“, konkluderer hun, ,,er ikke foder". Senest er Mary Douglas vendt tilbage til et klassisk strukturalistisk tema, den arbitrære modsætning mellem det spiselige og uspiselige (1996:145-60).

Den tredje tilgang er ikke let at hæfte et navn på, andet end et vagt ,,sociologisk“. ${ }^{3}$ Den sætter mad og drikke, som et kohærent system, i relation til andre systematiske aspekter ved den eller de specifikke lokale kontekster der unders $\emptyset$ ges. Et tidligt eksempel udgør Thorstein Veblens behandling af det prangende forbrug af ,livsmidler“ blandt den besiddende lediggængerklasse i Vestens ,pengekultur“ (1924:68-75).

Inspireret af Veblen, har antropologen Jules Henry senere hævdet at:

der findes næppe den kultur hvori mennesker ikke har formået at udforme en sondring mellem føde med høj status og føde med lav status, og hvor maden ikke bliver sat $\mathrm{i}$ forbindelse med selvbilledet (Henry 1972:289).

Henry brugte maden til at illustrere pengekulturens absurditeter og spild - som både han og Veblen burde have kaldt kapitalisme - og den skade på mennesker den frembringer.

Forholdet mellem mad og social klasse er et omfattende emne. Goody (1982) går til det fra et historisk komparativt perspektiv, mens Bourdieu (1984:167-225) anvender mad, drikke og spisning som indikatorer for klassebaserede livstilshierarkier som adskiller sig fra hinanden ved smagskriterier og forbrugsmønstre. Med afstandtagen fra klassebegrebet, sætter Gusfield (1992) forestillingen om „,naturlig mad“ i sammenhæng med ændringer i amerikanske modeller af samfund, sundhed og seksualitet. Med udgangspunkt i et videre perspektiv bruger Mennell (1985) europæiske smagsformer til at belyse en civiliseringsprocesmodel, afledt af Norbert Elias'. På det seneste har feministiske analyser, $\mathrm{i}$ bred forstand, fokuseret på tilberedningen og betydningen af mad og drikke som indflettet i kønsulighedssystemer (fx Benson 1997; Bordo 1993; Charles \& Kerr 1988; Delphy 1979; Ellis 1983; Murcott 1983).

De strukturalistiske og „,sociologiske“ tilgange til mad og drikke har meget til fælles og sameksisterer ganske udmærket med interesser i ernæring. Begge behandler mad og drikke som indeks for noget andet: der findes ingen størrelse som ,,mad i sig selv“ (givet- 
vis fordi der ikke er en ting som mad i sig selv). Mere præcist er det strukturalistiske antagelser om klassifikationens natur der præger „sociologiske“ forfatteres arbejde, som hos Bourdieu og Goody. Det nære slægtskab mellem de to tilgange illustreres af Marshall Sahlins' analyse af moderne amerikanske fødetabuer (Sahlins 1976:179ff.). Sahlins argumenterer her imod marxismens materialisme og økonomiens utilitarisme og fremhæver betydningens og kulturens relative autonomi. Han fremlægger en skitse til en struktureret symbolisering af det kulinarisk foretrukne og forskellen på spiseligt og uspiseligt - fx spiser amerikanere ikke heste, selvom deres hunde godt kan - og denne symbolisering står, via produktions- og markedsforhold, i systematisk relation til en lige så struktureret symbolisering af forskelle mellem personer. Lévi-Strauss og Douglas møder her Veblen og Henry.

Det som disse synsvinkler dog har allermest til fælles, er at de koncentrerer sig om produktet, mad og drikke, frem for om processen. Man kan finde diskussioner af tilberedningen af mad (fx den feministiske litteratur) og, færre og ikke så dybtgående, af spisning (fx Bourdieu og Mennell). ${ }^{5}$ Dog lægges der i overvældende grad vægt på de konkrete mad- og drikkesubstanser og på hvorledes de benævnes og klassificeres. Dette kan til dels forklares ved en, mere end blot tiloversbleven, anvendelsesinteresse i ernæring, selv i strukturalistiske og ,sociologiske“ tilgange. Denne vægtning kan imidlertid generelt bedre forklares ved:

- en fascination af de ,kulturelle menuers“ arbitraritet - forskellige befolkningers mad og drikke-repertoirer;

- den antagelse at kulturelle menuer danner betydningssystemer der fortæller os noget vigtigt; og

- mad og drikkes så iøjnefaldende vigtighed som hverdagsforeteelse og derfor som en umiddelbar bro til ikke-velkendte betydningsuniverser som forsker og udforskede kan krydse, i begge retninger.

Ingen af disse tilgange er nødvendigvis problematiske. Dog har denne relative overopmærksomhed på mad og drikke ført til at sociale processer og organiseringen af disse særlig spisning og drikning - i nogen grad er blevet overset. Kulturelle frembringelser og de meddelelser de kommunikerer, er vigtige, men det er - og undskyld disse grove sondringer som jeg normalt ikke ville forsvare: mellem det kulturelle og det sociale, mellem produkt og proces! - deres sociale produktions- og konsumptionsprocesser selvsagt også. Også de sociale processer er betydningsprægede. Dette beskedne forslag komplementerer de veletablerede antropologiske og sociologiske tilgange til mad og drikke; det må ikke ses som et alternativ til dem. Det bygger på følgende antagelser:

- spisningen og drikningens repertoirer er ikke mindre arbitrære end den mad og drikke der indgår deri;

- spisning og drikning danner et betydningssystem der fortæller os noget vigtigt; og

- spisning og drikning er en del af mad og drikkes vigtighed, en vigtig planke i den bro de lader føre over til ikke-velkendte betydningsuniverser.

I resten af denne artikel vil jeg fokusere på spisning og drikning. Mange etnografiske beskrivelser medinddrager spisning og drikning som facetter af de emneområder forskeren er interesseret i: udveksling, slægtskabsrelationer, gruppesolidaritet, ritual, lokal politik, kønsrelationer eller hvad det nu kan være. ${ }^{6}$ Her er det imidlertid selve spisningen og drikningen jeg interesserer mig for. 
Når jeg lægger hovedvægten på spisningen og drikningen som sociale hændelser, indebærer dette ikke en mangel på interesse i, endsige begejstring for, dansk mad og drikke. Det forholder sig snarere omvendt: når min interesse for hvordan denne eller hin ret skulle tilberedes, lokalt blev anset for at være tilstrækkeligt mærkværdig til at afføde kommentarer, var det oprindeligt netop det der gav anstød til de overvejelser der bringes til udtryk her. Danskere, forekommer det mig, er mere optaget af spisningen og drikningen som social hændelse end i hvad de spiser og drikker, og hvorledes dette fremstilles. Det betyder ikke at de ikke bekymrer sig om hvad de spiser og drikker - det gør de vitterlig - ej heller er dette en negativ kommentar til kvaliteten af dansk mad og drikke. Det drejer sig her om en relativ vægtning.

Denne tilgang må heller ikke få nogen til at tro at man ikke skulle kunne foretage strukturalistiske eller mere bredt anlagte sociologiske analyser af dansk mad og drikke. Fx kan der siges meget om de strukturelle forhold mellem de retter der udgør den danske frokost (jf. Schwartz 1991; Vestergaard 1995). Mit eget feltarbejde lægger op til andre analyseretninger. Hvad med fx klassifikationen af drikke i Danmark? Ethvert supermarked vil kunne være bevis på at $\emptyset 1$ klassificeres sammen med vand, og på et helt andet sted end ,rigtig“ spiritus. Denne klassifikation er hverken „naturlig“ eller selvindlysende undtagen selvfølgelig for danskere - og den er sigende. På samme måde kunne man bruge en del tid på sondringen mellem sauce og sovs og den symbolske vægt der tillægges sidstnævnte. Alt dette endda før vi er begyndt at se på lagkage, rundstykker søndag morgen (herom mere senere) osv. Måske kunne det blive emnet for en anden artikel.

\section{Spisning og driknings sociale kontekster}

Fra september 1996 til juli 1977 udførte jeg feltarbejde i Midtjylland, nærmere bestemt Skive $^{7}$ og omegn. Efter dansk målestok er Skive middelstor: kommunen har omkring 27.000 indbyggere hvoraf ca. 20.000 bor i selve byen. Skive fik købstadsrettigheder i 1326 og er i dag den tredjestørste kommune i Viborg Amt. Selvom den for mange skibonitter er universets centrum, et særligt smørhul (et synspunkt jeg aldeles tilslutter mig), er den også en meget almindelig dansk - eller for at være mere præcis og tage hensyn til lokal følsomhed - jysk by. Skive er ganske repræsentativ for mange sider af det danske samfund.

Lokaløkonomien er blandet. Skønt den offentlige sektor er det største enkelte beskæftigelsesområde, er der mange små til middelstore erhvervsvirksomheder og en stor privat servicesektor. Skive er centrum for Sallings blomstrende landbrug og de mindre frugtbare områder mod syd. Arbejdsløsheden omfatter omkring fem procent af den arbejdsdygtige befolkning. Den er også et uddannelsescentrum med et seminarium, en højskole, en teknisk skole, en handelsskole og et gymnasium. Studenter hører til blandt de mest synlige indbyggere. Med dens store moderne artillerikaserne gælder dette også soldater, både menige og konstabler. Apropos synlighed, så har Skive siden 1990'erne ændret sig fra at være relativt etnisk homogen til noget mere sammensat. Selvom total nøjagtighed er umulig, så udgøres nu - ifølge de lokalmyndigheder der beskæftiger sig med situationen - mere end fem procent af befolkningen af immigranter: mest flygtninge, overvejende muslimske, fra forskellige mellemøstlige lande. Ved kommunevalget i no- 
vember 1997, og i tråd med tendenser i landet som helhed, fik byen en konservativ borgmester efter mere end tres år med socialdemokratisk styre, og anti-indvandrerpartiet Dansk Folkeparti voksede fra et til to byrådsmedlemmer.

Hvad angår mad og drikke, så spiser de fleste danskere det meste af tiden hjemme, og skibonitter er ingen undtagelse. Husholdningernes menuer varierer fra familie til familie. Hos nogle er hjemmelavet mad det almindelige, om det så er „traditionel“ dansk mad, såsom smørrebrød eller dansk bøf med løg eller noget mere eksotisk som pasta. Hos andre er det dog færdiglavet mad som frossen biksemad, pizza eller burgere der udgør den daglige norm. De lokale forretninger afslører et mønster af valgmuligheder for tilberedning og spisning som i grove træk er velkendt over hele Europa. I et samfund hvor flertallet af både mænd og kvinder er fuldtidsbeskæftigede, må ,gennemsnitshusholdningen“" støtte sig til en kombination af det hjemmelavede og det færdiglavede.

I et sådant samfund må man også gå ud fra at mænd og kvinder deler ansvaret for tilberedningen. Dette holder i nogen grad stik: danske mænd synes stort set at tage deres del af køkkenarbejdet. Men det er dog også sandt at i mange husholdninger fastholdes den traditionelle kønsbaserede kulinariske arbejdsdeling: kvinder laver mad, mænd spiser. Det er delvis et generationelt forhold: ældre mennesker er mere tilbøjelige til at følge ældre adfærdsmønstre. I mange andre husholdninger, og det uanset generation, er det der menes at være „,vanskelig“ madlavning - til gæster, bagning, desserter osv. - stadig kvindearbejde. Og i mange husholdninger er spørgsmålet uden betydning. I 1993 havde lidt over 30 procent af alle husholdninger i Skive kun ét medlem (Skive Kommune 1994:423). Når man tager med i betragtning at mange forældre - langt de fleste kvinder - er enefors $\varnothing$ rgere, er antallet af lokale husholdninger med kun en voksen langt større; tallet for hele landet ligger omkring 55 procent og er stigende (Nordic Statistical Secretariat 1995:55).

Hvad man skal forstå ved et hjem eller en husholdning, er dog hverken oplagt eller ligetil i Danmark. En af grundene til at Danmark er interessant for en udefrakommende iagttager, er variationerne i de forskellige husholdnings- eller samlivsarrangementer, særegne kollektive arrangementer af forskellig slags (Power 1993:239-305). I Skive er der nogle bofællesskaber og andre former for kollektive boliger som huser forskellige beboergrupper, ${ }^{8}$ selvom den andel af det samlede antal husholdninger de repræsenterer, givetvis er mindre end i større byområder: ca. 580 hjem eller hushold anvender fx fælles køkkenfaciliteter (Skive Kommune 1994:35). I de fleste fællesboligformer skiftes medlemmerne til at lave mad til kollektivet eller beboergruppen. Dertil kommer at naboer i visse ikke-kollektive boformer, beboerforeninger fx, danner fællesspisningsgrupper hvor de regelmæssigt laver mad til hinanden (selvom dette også er mere almindeligt i større byer).

Skibonitter spiser nu heller ikke altid hjemme, hvad så end ,hjemme“ betyder. Selv når de gør det, kan maden være tilberedt et andet sted og af andre. Ta'-med-hjem-mad er lige så populær her som overalt i Danmark og Europa. Og til trods for at der i Danmark ikke er nogen stor tradition for at spise og drikke ude - slet ikke i sammenligning med den britiske ,pubkultur“" eller Middelhavsområdets ,cafésamfund“-er der tilstrækkeligt mange der gør begge dele og dermed sikrer at mulighederne herfor står til rådighed. I Skive er der et spektrum af valgmuligheder mellem kommercielle spise- og drikkesteder som vi kan opstille i stigende orden, fra lavere kulturel status og bekostelighed til højere, fra lavere tilvirkningsgrad til højere: 
- pølsevogne (mindst tre);

- smørrebrødsforretninger (en i bycentret og et lille firma der leverer på bestilling);

- grillbarer og cafeterier (som også udskænker øl);

- pizzaforretninger (mindst syv, hvoraf nogle er rene ta'-med-forretninger og hvoraf de fleste har mellemøstlige ejere);

- McDonald's (som åbnede lige efter jeg kom til Skive);

- etniske restauranter og cafeterier (kinesiske, indiske, vietnamesiske, italienske);

- ,regulære“" værtshuse;

- andre værtshuse, hvoraf nogle benævner sig selv pubber, og som laver mad, typisk

til frokost;

- restauranter, og i den landlige omegn, kroer der - og atter kun typisk - serverer

dansk mad;

- hotelrestauranter (der er to i byen).

Disse er helt offentlige spisesteder hvor alle kan gå ind for at spise og/eller drikke. Det er umuligt her at komme ind på alle de nuancer som skiller dem fra hinanden. For hvordan skal man i grunden klassificere „Restaurant Rosies“, også kendt som „Bobby McGee“ og „Eldorado“, hvor der serveres røde bøffer, spareribs og anden ,amerikansk“ mad - i omgivelser der giver sig ud for at kunne tilbyde en engelsk pubs atmosfære? Foretagender af denne art - og de ejes og køres af danskere og bærer så autentiske navne som Rio, Eldorado osv. - har længe været en del af det danske bylandskab. Globaliserede, javel, men bestemt ikke etniske (bortset fra at være overmåde danske).

Men vi finder også mange halvoffentlige spisesteder: steder hvor man kan bestille selskabsmad og andre serviceydelser, musik fx, til fester, jubilæer og fødselsdage og andre højtidelige anledninger. Sådanne sammenkomster kan alene være forbeholdt inviterede gæster, de kan være åbne for dem der har skaffet sig billetter (som ved nogle af de arrangementer der er organiseret af foreninger), eller de kan være åbent-hus-arrangementer, der ofte annonceres i de lokale aviser og derfor er åbne for venner, naboer, arbejdskolleger og andre af værtens bekendte. Rammerne for disse festligheder stilles til rådighed af kroer, hoteller og enkelte cafeterier - som omtalt ovenfor - og de reklamerer med en særlig art faciliteter til dette formål: selskabslokalet. I Skive findes der også andre feststeder på dette lukrative marked: Skivehallen, det lokale teater, den lokale danseskole og -klub, andre klubber og foreninger (fx Sejlklubben), og i mange af de omkringliggende landsbyer og forstæder, det lokale forsamlingshus.

Hvad angår forsamlingshuse - der er opført 14 i lokaltelefonbogen for Skive ${ }^{9}$ - er adgangen til deres faciliteter almindeligvis en del af at have gjort sig berettiget til at deltage i landsbyens eller nabolagets kollektive selskabelighed. Madlavningen, serveringen og andre sider af festens organisering kan de der holder festen selv stå for, eller den kan være overladt til forsamlingshusets bestyrer. Den kommercielle udlejning af selskabslokaler og navnet er i sig selv sigende: vægten ligger netop på selskabelighed, det ældre danske ord for sociabilitet - kan, i det mindste i nogle henseender, betragtes som en erstatning for forsamlingshuse i bymæssige, mindre selskabelige og fællesskabsorienterede nabolag.

\section{Sociale anledninger til spisning og drikning}

Der findes flere anledninger til at spise og drikke end der findes steder til at gøre det. Her 
vil jeg se på fem kategorier af anledninger, og de er udvalgt således at de skulle kunne illustrere et kontinuum fra det mest private til det mest offentlige.

Og det mest private er rutinespisningen hjemme hvor der selvsagt findes tre grundformer: morgenmad, frokost og aftensmad. Morgenmaden vil i en eller anden form - om så den blot består i en kop kaffe - blive indtaget hver morgen. For de fleste er det dog kun i weekenden den er mere end et fortravlet forspil til resten af dagen. Men når nu lørdage i mange hjem er lige så travle som hverdage, finder morgenmaden som en større spisningshændelse i sig selv primært sted på søndagsmorgener. Folk kører eller cykler til den ene lokale bager der sælger friske rundstykker og morgenbrød, køber en avis, kommer hjem og spiser blødkogte æg osv. i ro og mag - en såre genkendelig institution:

...hvis du vil se dansk kultur, skulle du tage hen til bageren oppe på Aage Nielsensvej en søndag morgen. Det er meget vigtigt for mange danskere at få frisk brød om søndagen. Det gør de ikke de andre dage fordi de har så travlt, men på søndage vil du kunne se en lang kø. Dér vil du se dem, og nogle af dem er klædt, ja, det kunne næsten være i pyjamas, men dog i joggingtøj og den slags. Der er en der holder døren åben, og ingen af dem taler med hinanden, medmindre de træffer på nogen de kender; de går ind... de tager en avis, køber deres brød, rundstykker til morgenmaden, og går hjem. Der er parkeret biler overalt. De har så travlt.

Søndag uden morgenmad er ikke en rigtig søndag, og morgenmad uden friske rundstykker er faktisk ikke rigtig morgenmad overhovedet.

Frokost hjemme er også en typisk weekendtildragelse. Den kan antage mange former, afhængigt af om der er gæster osv. Den konventionelle form for en ,rigtig“ frokost er rugbrød og franskbrød med fisk, kødpålæg og ost, indtaget i den rækkefølge. Øl er faktisk ikke obligatorisk, selvom det nogen gange kunne se sådan ud, og snaps er kun obligatorisk hvis der er gæster eller skåler at udbringe. Frokosten kan være meget kunstfærdigt udformet, som ved de rituelle frokoster, især ved jul, påske eller pinse, men vigtigst er det at man følger de grundlæggende regler: fisk før kød før ost, og skift tallerkener mellem fisk og kød osv! Der er selvfølgelig mange måder at spise frokost på, og hvis det ikke ligefrem drejer sig om en ,traditionel“ frokost, øges antallet af variationer hurtigt. Måske består det eneste grundprincip i at frokost typisk er et koldt måltid baseret på brød.

Aftensmaden er endnu mere åben for valg og opfindsomhed. Der findes meget få regler om hvad man skal spise ud over den velkendte tredelte, nordeuropæiske struktur med forret, hovedret og dessert og de lige så fælles nordeuropæiske regler om at hvis der serveres suppe og hovedret, kommer suppe først, og hvis både fisk og kød serveres ved samme måltid, så kommer fisk almindeligvis først. Hvis man drikker vin frem for $\emptyset 1-o g$ det vil være vin hvis der er gæster - vil det mest sandsynligt være rødvin, hvad hovedretten end består $\mathrm{i}$.

Det afgørende ved at spise hjemme er den tydeligt formulerede vigtighed og betydning der knyttes til det at spise sammen (endog, og hvis muligt, under morgenens travlhed). Fællesspisning er grundlæggende for det at leve sammen. Inden for denne fælles og aksiomatiske sociabilitet, adskiller måltider sig dog ved deres forhold til den privatoffentlige dimension. Morgenmad er det mest private; søndag morgen kan denne privathed endog udstrækkes til relationerne mellem dem der står i kø sammen for at få brød. Frokosten - som er måltidet der er længst adskilt fra søvnens intimiteter - er det mest offentlige. Frokostinvitationer indebærer mindre familiaritet end middagsinvitationer. 
At måltiderne overalt hvor det er muligt, bør leve op til deres velkendte form er også særdeles betydningsfuldt. Og selvom de angribes af globaliserende indflydelse fra masseproducerede fødevarer og måden disse markedsføres på, og af påvirkninger fra en moderne livsførelse og et moderne arbejdsliv, har danskere meget faste og konventionelle ideer om hvad morgenmad, en frokost og en middag bør være. Og det er vigtigere at formen er korrekt, dvs. velkendt, end at maden er i særklasse god. Det er næppe tilfældigt at frokosten, det mest offentlige måltid, og derfor også potentielt åbent for uforudsigelighed, styres af den højeste grad af formel strukturering (Kaivola-Bregenhøj 1997; Schwartz 1991; Vestergaard 1995).

Etikette er et andet aspekt ved formen. Hvis anledningen kan bestemmes som et rigtigt måltid - og fx ikke blot et fortravlet morgenmåltid - skal de der spiser, takke den der har tilberedt maden. „Tak for mad!“, fulgt af svaret „,Velbekomme!“, udgør en automatisk formel høflighedsform, men er ikke derfor mindre meningsfuld. Den er rutine i forholdet mellem forældre og børn i dettes privathed, og jeg har hørt det for ofte til at kunne forestille mig at der er tale om en form for høflighed der kun gennemspilles for gæstens skyld - også i mere offentlige udvekslinger mellem gæster og værter. Det er det absolutte minimum af taksigelser der forventes (Kaivola-Bregenhøj 1997:282-3). At undlade at sige tak er vitterlig en grov forsømmelse og ikke en ny tilføjelse til dansk etikette (Redlich 1939:15-6).

Hvis man spiser sammen med nogen der ikke hører med til husholdningen, bør man sige „Tak for sidst!“ næste gang man møder dem, selvom det kan være længe siden; det påkrævede svar er „Selv tak!“.. Det er sigende, da disse takker er egalitære og gensidige. Hvad enten man nu er vært eller gæst, kan man legitimt fremsige begge former (og det kan selvsagt føre til en mild konkurrence om hvem der får sagt ,Tak for sidst!“ først). Det er kvaliteten ved den sociale begivenhed - fællesskabet og selskabet - ikke maden der værdsættes. Man kan fx også sige „Tak for sidst!“" som påskønnelse af en aften på værtshus eller en strandtur.

Hygge, dette så ofte omtalte og upræcise danske fænomen, udgør et andet aspekt ved formen og etiketten for at spise sammen. Hvordan skulle man fx kunne spise middag, især når der er gæster, uden stearinlys i rummet, om ikke på selve bordet? Og er det muligt at det at spise alene kan være hyggeligt? At spise sammen er både middel og mål når det drejer sig om den sociale produktion og orkestrering af hygge.

At spise og at drikke er i Danmark både offentligt og privat stærkt ordensstyret, om end ikke fuldstændig regelbundet. Regler og form kan meget vel være blevet mere afslappede siden førsteudgivelsen i 1918 af Emma Gads håndbog i god opførsel (Gad 1985), men det er slående i hvor høj grad Gad er forblevet en god vejviser. Folk ved hvad man kan forvente, og de kan lide at vide hvad man kan forvente. Måltider bør først og fremmest være sociale begivenheder, og de bør være rimeligt forudsigelige. Som ved dansk samfundsliv i almindelighed maskerer den afslappede familiaritet og hyggelige samværsform og konverseren omkring bordet en underforstået og stramt struktureret orden. Disse regler for selskabelig sam-spisning udgør hvad Goffman (1983:5) kaldte ,muliggørende konventioner“: rammer der må tages for givne og som tillader den selskabelige og sociale afslappethed at trives (og som er behagelige i det omfang man bemestrer disse rammer, dvs. er dansk).

Enighed sættes højt i dansk samfundsliv, selvom det at tale om enighed kan være vigtigere end at opnå den og kan maskere betragtelig uenighed. Det er jo svært at være uenig 
med nogen når man spiser sammen, eller ligefrem er sammenspiste! Derfor er min anden kategori af spise- og drikkehændelser m $\phi$ det. At træffe beslutninger, eller legitimeringen heraf, ved hjælp af møder og samtale står centralt i dansk organisationsliv, især - omend ikke udelukkende - i den offentlige sektor. Møder kan være mange ting, men om nu det er et personalemøde, et møde mellem et firma og dets kunder, forhandlinger mellem arbejdsgivere og fagforeninger, et foreningsbestyrelsesmøde, et forældremøde eller til og med, som visse steder i Salling, et byrådsmøde, vil et formelt arrangeret møde typisk ledsages af spisning og drikning.

Der er altid sørget for mad og drikke, og det er usædvanligt at det bliver bragt med af deltagerne. Det vil i almindelighed stå på bordet, mellem folk. Nogle gange vil denne spisning og drikning først finde sted efter afviklingen af dagsordenen. Fravær af mad og drikke, i det mindste kaffe, $\emptyset \mathrm{l}$ og sodavand, ville givetvis få et par kommentarer med på vejen. I de fleste tilfælde er mad og drikke her en symbolsk gestus (når man tænker på at danskere elsker at tale, kan drikningen dog bidrage til smøringen!). Maden kan være så ubetydelig som blot et par rundstykker med kaffe, og den har også kun lidt at skaffe med tidspunktet på dagen. Det handler alt sammen om sociabilitet, etablering af den rigtige atmosfære, og skabelse af betingelserne hvorunder enighed vil kunne opnås eller, i det mindste, muliggøres.

De fleste møder er private. Mindre privat er min tredje kategori af spisnings- og drikkehændelser, generalforsamlingen. Selvom man kan argumentere for at foreninger er på tilbagetog, udgør de stadig sociale kerneorganisationer i Danmark (Balle-Pedersen 1976), og måske i Skandinavien mere alment (Salamon 1992). Emma Gads spørgsmål: „Hvem er ikke Medlem af en Snes Foreninger eller noget deromkring?“ (1985:135), lyder stadig troværdigt i Midtjylland.

Nøglerne til at forstå foreningslivet er at foreninger, for det første, er frivillige sammenslutninger som, for det andet, arbejder kollektivt gennem dannelsen af tilstrakkelig kommen overens til at muliggøre at tingene bliver gjort. Den årlige generalforsamling er afgørende for denne proces, og det er vigtigt at udforme den sociale side af denne hændelse på rette vis.

Generalforsamlingernes hovedsæson er mellem nytår og påske. De varierer fra små møder til store begivenheder, dækket af de lokale tv-nyheder, som fx dem de lokalt baserede sparekasser afholder. Forløbet ledsages altid af spisning - gule ærter er generalforsamlingernes favoritmåltid, alt efter årstiden og omkostningerne - og drikning, og ofte underholdning. Her har vi fx en generalforsamling i et landsbyforsamlingshus, nogle få kilometer uden for Skive:

120 stykker smørrebrød, to flasker snaps, $\emptyset 1$ ad libitum - og 23 Ramsingmænd. Der skal være generalforsamling i Ramsing Vandværk.

'Som ordstyrer vil jeg gerne opfordre til at der bliver rakt til drikkevarerne på bordet. Og så skal vi høre formandens beretning'.

Indholdet af et A4-ark afleveres lynhurtigt. Der skåles, og der skåles igen, inden kassereren læser regnskabet op. Og så skåles der lige en gang til. For hyggens skyld.

Der vælges bestyrelse, og diskussionen afklares i en håndevending. En halv time, og der takkes for god ro og orden med en skål.

Efter et par timers summen og mere højrøstet mandesnak om landbrug, den manglende snaps og det fine smørrebrød blandt meget andet, begynder det så småt at trække op til kortspil... (Sørensen 1997). 
Kvaliteten af maden og drikkevarerne er vigtig, men aftenens hovedpunkt er den virkningsfulde kombination af hygge, fællesskab og enighed som bidrager til en effektiv forening.

Min næste kategori af spise- og drikkeanledninger er fester. Danskere fejrer mange ting: fødselsdage (især de ,runde“), bryllupper, bryllupsdage (de har til og med opfundet én for 12 1/2 år), andre jubilæer, barnedåb, konfirmationer, beståede eksaminer osv. For da slet ikke at tale om de festligheder kalenderen foreskriver: jul, nytår, fastelavn, påske, pinse, mortensaften (som har mistet betydning) samt alle de andre helligdage... Fejringer af mærkedage i livsforløbet i familien forbliver dog de vigtigste, og der er en række forhold ved dem som bør udhæves:

- deres omfang og omkostninger (de kan være store og kostbare);

- den voksende tendens til at afholde dem på halvoffentlige lokaliteter frem for hjemme;

- det underdrevne - Janteloven er aldrig blevet sat ud af kraft - prangende forbrug og den konkurrence det indebærer;

- vigtigheden af kvalitet og veletableret konvention som de principper der styrer madleveringen;

- deres rolle som kontekster hvori man giver og modtager gaver.

Da Tolkien (1966:11) sagde at hobitter var ,flinke til at spise og drikke [...] gæstfri og glade for selskaber og for gaver", kunne han have været i færd med at beskrive danskere. Som lærd udi oldnordisk, var det måske også det han gjorde. Gavegivningen er nu så institutionaliseret i Danmark at den må udgøre en betragtelig dimension i værdicirkulationen i enhver lokal $\varnothing$ konomi.

Hvad der hidtil er blevet sagt om selskabelighed, form og etikette, gælder med lige så stor kraft - og at det kun er lige så stor kraft, er afgørende - om fester. Men fejringer har også deres særlige træk: især taler, sange og sketcher. Taler ved denne slags sammenkomster er ikke et enestående dansk fænomen (om end deres antal, og det forhold at de ofte ikke indskrænkes til nøgledeltagerne, vel kan være det). Det er imidlertid et særkende at deltagere skal medbringe trykte eller fotokopierede sange, almindeligvis til velkendte melodier, som de selv har skrevet til lejligheden eller har bestilt hos nogen med sangskrivertalent. Sangene priser eller driller de(n) person(er) hvis dag det er, og de vil alle blive afsunget. ${ }^{10}$ På samme måde kan gæster fremføre små sketcher som udfylder samme funktion.

Disse performative aspekter ved festen kan finde sted mellem retterne, eller mellem første og anden ombæring af samme ret. Man kan enten se på dem som afbrydelser i maden og drikningen eller som mere vigtige for begivenheden end mad og drikke. Hvad man nu end måtte mene derom, er resultatet at måltider nogle gange tager meget lang tid, og i den proces at skabe hygge og godt fællesskab og frembringe alle hændelsens forventede elementer, forbedres hverken maden eller den formelle underholdnings kvalitet nødvendigvis. Som dette udpluk fra mine feltnoter viser, er da heller ikke alle lige begejstrede:

Poul huskede et sølvbryllup han og Marianne engang var til hvor der var femten sange, så de ikke var færdige med kartoflerne før klokken et om morgenen... Og musikken gik hjem halv to efter at have spillet under hele måltidet. Det var for meget af det gode, sagde han, især da mange af sangene ikke var personlige, de var kun kopier af andre sange. 
Selvom tilfældet er ekstremt, og måske en smule - men også kun en smule - overdrevet, viser det pointen.

Al denne drikken, og vi må ikke forglemme at der drikkes, kan afstedkomme problemer næste morgen. Når tømmermændene melder sig, vil kun en ting kunne fordrive dem: en hotdog med det hele, skyllet ned med - og her findes der to danske tankeretninger enten Coca Cola eller chokolademælk (kendt blandt skibonitter som en Congobajer).

Som et ubetvivleligt højdepunkt i det danske køkken - hvor de såkaldte ,franske hotdog“" sandsynligvis er det laveste - bringer ,den rigtige“ hotdog mig til min sidste kategori: offentlig spisning og drikning, på opfordring og efter behov. Ernæring - i det mindste næring - kan vel her være mere vigtig end ved nogen af de andre lejligheder vi har omtalt indtil nu: når den bliver nødvendig, som tømmermændskur eller ej, så er den virkelig nødvendig. Vi går let hen over de andre muligheder, McDonald's, grillbarer osv., for kernestedet $\mathrm{i}$ offentlig spisning efter behov i Danmark forbliver, som allerede antydet, at stå ved pølsevognen. Og selv her, hvor madens udsøgthed og kvalitet er begrænset - og omdømmet såre vigtigt - er det selskabelige ikke mindre betydningsfuldt end maden. Man går ikke altid hen til pølsevognen fordi man vil have en hotdog (eller medister eller hvad det nu kan være). Man skal måske af med et par nyheder eller høre nogen, møde nogen som aftalt, brokke sig over regeringen, gennemgå den og dens tossestreger aftenen før, finde læ for regn og vind osv. Som en skibonit sagde det til mig:

I går tog jeg Patrick [hans søn] med hen på McDonald's, for det havde jeg lovet ham. Jeg ved ikke hvorfor han ville derhen. $\mathrm{Og}$ når du går ind, ser du dig omkring, på farvereklamerne, og alt hvad de kan der, drejer sig om at være hurtig. Vi fik en burger, og jeg ved ikke hvad den lugtede af... For, forstår du, i Danmark går du ikke hen til pølsevognen for at spise pølser... Du går hen til pølsevognen for at spise ord, for at tale med pølsemanden. $\mathrm{Og}$ du vil ikke kunne forestille dig at snakke med nogen af de tåbelige folk hos McDonald's.

En god og strategisk placeret pølsevogn er et centralt koblingspunkt for mange forskellige sociale netværk, en veritabel informationssupermotorvej. Det er fx intet tilfælde at de to vigtigste pølsevogne i Skive står foran rådhuset og posthuset. De danner midtpunkt i en social interaktion og er ikke blot affodringsstationer. For at vende tilbage til Mary Douglas: føde er ikke foder. Ved pølsevognen behøver det endda slet ikke være nødvendigt at spise, men det er nødvendigt at tale (Andersen 1972:32-4). ${ }^{11}$

\section{Den sociale betydning af at spise og drikke}

Nuvel, hvad kan dette hastige, og ufuldstændige, kig på spisning og drikning fortælle os om Danmark, i dette tilfælde en by i Midtjylland? Nogle få almene konklusioner tilbyder sig selv. Den mest generelle, og det er næppe en omvæltende indsigt, er at det at spise og drikke i Danmark er yderst sociale processer som befinder sig lige i hjertet af dansk samfundsliv. Kun få ting er lokalt og kulturelt vigtigere. Hvad mere er, de sociale lejligheder der omgiver spisning og drikning, kan man med fuld ret se som mere betydningsfulde end mad og drikke i sig selv. I spisning og drikning - i Danmark og formentlig alle vegne forvikles sociale midler og kulturelle mål med hinanden, fuldstændigt og uigenkaldeligt.

En række andre almene temaer træder frem. For det første foretrækker danskere at tingene er behagelige og forudsigelige hvor det er muligt. Orden er vigtig. For det andet 
værdsættes en relativt harmonisk sociabilitet højt - om så den måske er af den formelagtige og overfladiske slags. Dette sammenfattes $ø$ konomisk i det danske ord - som det næsten er umuligt at oversætte dækkende til andre sprog - fælles, som i fællesskab, fællessang, fællesfølelse og, ja, fællesspisning. Der gemmer sig en bitter ironi i dette, for det bliver mere og mere almindeligt at danskere bor alene - i sammenhænge hvor det kompleks af værdier der sammenbindes i ,fælles“, er en fjern, om ikke umulig, vision. Herfra kommer, måske, en kollektivistisk leveform - især og i stigende grad for ældre mennesker - og vigtigheden af de halvoffentlige spise- og drikkeanledninger og disses lokale rammer. Ligesom grænsen mellem stat og civilsamfund i Danmark er uklar og uskarp, er grænsen mellem offentlig og privat det også. Så herfra kommer måske også - og dette er en tentativ idé der må begrundes bedre - den etikettetryghed der skaber det-offentlige-idet-private og det-private-i-det-offentlige.

Etikette drejer sig også om at holde folk på deres samfundsmæssige plads. Hvor etiketten i Storbritannien i det store og hele har drejet sig om bevarelsen og styringen af hierarki, kan man med nogen ret hævde at dansk etikette primært drejer sig om bevarelsen af en offentlig fiktion om relativ lighed. Egalitær enighed og konsensus - eller i det mindste tilsyneladende enighed og konsensus - betragtes som den bedste måde at få tingene gjort på, overalt hvor det er muligt. Den tilsyneladende afslappethed og uformalitet i samfundslivet - som hygge er indbegrebet af - der letter vejen for harmoni og konsensus, er bygget op på et skelet af alment accepterede og fælles sociale konventioner og interaktionelle normer hvoraf nogle tages for givne, og nogle er eksplicitte. Selvom det ville være en overdrivelse at beskrive dem som repressive, kan de som alle alment delte og værdsatte konventioner lejlighedsvis få tvangspræg.

Ironien ved den „tvangsmæssige hygge“ har man klart forstået lokalt.

Etikettereglen for gensidige taksigelser - som jeg her blot har berørt kort - og vigtigheden af gavegivningen, leder tanken hen på cirkulationen af værdier, og værdien af cirkulationer, i Danmark. Her udtrykt af en lokal forretningsmand der bittert beklagede sig over den offentlige sektor og velfærdssystemet:

alt bare bevæger sig rundt i en stor cirkel. Du tager det op af din lomme, og det kommer ned i min. Og så tager jeg det op af min lomme og kommer det $\mathrm{i}$ din. Og så videre, i en stor cirkel.

Hans kommentar rakte videre end han måske selv vidste. Spisning og drikning frembyder nogle af de vigtigste hverdagskontekster hvori denne cirkulation virker.

Fællesskab, enighed, konsensus og værdicirkulation. Dette var centralt for de kooperative bevægelser der i det nittende århundrede bidrog så vigtigt til moderniseringen af det danske samfund. Brugsforeninger - og mere bredt foreninger - har været centrale omdrejningspunkter i det særlige danske forhold mellem stat og civilsamfund, og mellem det offentlige og det private. Som denne artikel har vist, er de værdier og principper de udtrykker, stadig vigtige i det danske samfund i dag, også selvom de i voksende omfang bestrides. Måske er Danmark endnu i mange henseender en brugsforening.

Oversat af Kennet Pedersen 


\section{Noter}

1. I et interview jeg har set på videobånd af den historieserie på tv, Gamle Danmark, der er produceret af journalisten Poul Hammerich.

2. Jeg tilbragte en måned i hver af somrene 1993 og 1994 i Danmark. Systematisk feltarbejde i Midtjylland fandt sted mellem september 1996 og juli 1997 (og jeg har genbesøgt Skive adskillige gange siden). Jeg er University of Sheffield taknemmelig for at have muliggiort dette feltarbejde.

3. Dette indebærer en intellektuel definition af sociologien, som ville indbefatte socialantropologien, snarere end en institutionel definition (Jenkins 1997:3-15). Hensigten er ikke at rubricere strukturalismen som usociologisk (om end noget af den er).

4. Det er en skam at Veblen og Henry overses af de fleste nutidige sociologer og antropologer.

5. På grund af bekymringer over alkoholforbrug, og alkohols rolle i ritualer og som stimulans og ,socialt smøremiddel“", har drikning tiltrukket sig større opmærksomhed (jf. Douglas 1987). Den opmærksomhed har imidlertid ofte ført til at man behandler drikning som en aktivitet af en anden orden end spisning. Den tilgang jeg foreslår, søger i et vist mål at anbringe de to praksis inden for samme analytiske ramme.

6. Eksempler på denne „,bi“-behandling af mad og drikke, spisning og drikning, i Danmarks etnografi indbefatter: Christine Morisset Andersens korte behandling af den historiske anvendelse af vilde planter og Limfjordens forskellige fruits de mer blandt landsbybeboerne i Gøl (1991:41-4); Anderson \& Anderson om „livets højdepunkter“ (1964:83-105) og rutinemadlavning (op.cit.:50) på 1950'ernes Amager og også Barbara Gallatin Andersons retrospektive redegørelse for det familiære spisested under feltarbejde (1990:3545); Steven Borish’ oversigt over „hygge“ (1991:264-80); Andrew Bucksers sammendrag af den årlige festligheds- og ritualcyklus på Mors (1996:66-74); Thomas Højrups mange henvisninger til spisning og drikning i sine detaljerede beskrivelser af forskellige familielivsformer på Sallingegnen og deres daglige rutiner (1989:73-176); Prakash Reddys afsnit om mad i Hvilsager (1993:140); og Cecilie Rubows en passant henvisning til "gravkaffe“ efter en begravelse (1993:29).

7. Andre nyere beskrivelser af området indbefatter: Højrup (1989), Haastrup \& Ottesen (1996), Møllgaard (1984); Skive Kommune (1976), Skov- og Naturstyrelsen (1995).

8. I forbindelse med valg af kollektiv bolig i sammenhæng med ældres boligbehov i Skive, henvises til Lindstrøm (1995).

9. Dette antal udelader et selskabslokale i omegnen - $\mathrm{i}$ forstaden Vinde - da det sandsynligvis bedst kan anses for at være en slags forsamlingshus.

10. Hvorledes dette syngeri er placeret i dansk samfundsliv, fortjener en artikel helt for sig.

11. Jeg skylder Stephen Mønsted tak for at have gjort mig opmærksom på denne dejlige Benny Andersen-ting og for at låne mig den mens jeg skrev denne artikel.

\section{Litteratur}

Andersen, Benny

1972 Svantes viser. København: Borgens Forlag.

Andersen, Christiane Morisset

1991 Les paysans-pêcheurs: Le passé et le présent d'un village de la région du Jutland Nord

(Danemark). Erslev: Vilsund Forlag.

Anderson, Barbara Gallatin

$1990 \quad$ First Fieldwork: The Misadventures of an Anthropologist. Prospect Heights: Waveland Press

Anderson, Robert T. \& Barbara Gallatin Anderson

1964 The Vanishing Village: A Danish Maritime Community.

Seattle: University of Washington Press. 
Balle-Petersen, Margaretha

1976 Foreningstiden. Det forsømte århundrede. Arv og Eje:43-68.

Benson, Susan

1997 The Body, Health and Eating Disorders. I: K. Woodward (ed.): Identity and Difference. London: Sage.

Bordo, Susan

1993 Unbearable Weight: Feminism, Western Culture and the Body. Berkeley: University of California Press.

Borish, Steven

1991 The Land of the Living: The Danish Folk High Schools and Denmark's Non-Violent Path to Modernization. Nevada City: Blue Dolphin.

Bourdieu, Pierre

1984 Distinction: A Social Critique of the Judgement of Taste. London: Routledge \& Kegan Paul.

Buckser, Andrew S.

1996 Communities of Faith: Sectarianism, Identity and Social Change on a Danish Island.

Providence \& Oxford: Berghahn

Charles, Nicola \& Marion Kerr

1988 Women, Food and Families. Manchester: Manchester University Press.

de Garine, Igor

1994 The Diet and Nutrition of Human Populations. I: T. Ingold (ed.): Companion Encyclopedia of Anthropology: Humanity, Culture and Social Life. London: Routledge.

Delphy, Christine

1979 Sharing the Same Table: Consumption and the Family. I: C. C. Harris (ed.): The Sociology of the Family. Sociological Review Monograph 28. Keele: University of Keele.

Douglas, Mary

1975 Implicit Meanings: Essays in Anthropology. London: Routledge \& Kegan Paul

1982 In the Active Voice. London: Routledge \& Kegan Paul.

1987 Constructive Drinking: Perspectives on Drink from Anthropology. Cambridge: Cambridge University Press.

1996 Thought Styles. London: Sage.

Ellis, Rhian

1983 The Way to a Man's Heart: Food in a Violent Home. I: A. Murcott (ed.): The Sociology of Food and Eating. Aldershot: Gower.

Gad, Emma

1985 [1918] Takt og Tone: Hvordan vi omgaas. København: Gyldendal.

Goffman, Erving

1983 The Interaction Order. American Sociological Review 48:1-17.

Goody, Jack

1982

Cooking, Cuisine and Class: A Study in Comparative Sociology. Cambridge: Cambridge University Press.

Gusfield, Joseph R.

1992 Nature's Body and the Metaphors of Food. I: M. Lamont \& M. Fournier (eds.): Cultivating Differences: Symbolic Boundaries and the Making of Inequality. Chicago: Chicago University Press.

Henry, Jules

1972 Culture Against Man. Harmondsworth: Penguin. 
Højrup, Thomas

1989 Det glemte folk: Livsformer og centraldirigering. København: Institut for Europæisk Folkelivsforskning \& Statens Byggeforskningsinstitut.

Haastrup, Lisbeth \& Laila Ottesen

1996 Kultur- og fritidslivet i Salling-Fjends - Statusrapport og idéoplæg op til kulturregionsforsøget. Gerlev: Center for Idrætsforskning.

Jenkins, Richard

1996 Social Identity. London: Routledge.

1997 Rethinking Ethnicity: Arguments and Explorations. London: Sage.

Kaivola-Bregenhøj, Annikki

1997 Ekskurs i den danske madkultur. I: E. M. Kofod \& E. K. Mathiesen (red.): Traditioner er mange ting. Festskrift til Iørn Piø på halvfjerdsårsfødselsdagen den 24. august 1997.

Skrifter nr. 88. København: Foreningen Danmarks Folkeminder.

Kuper, Jessica (ed.)

1977 The Anthropologists' Cook Book. London: Routledge \& Kegan Paul.

Lévi-Strauss, Claude

1970 The Raw and the Cooked: Introduction to a Science of Mythology, Vol. 1.

London: Jonathan Cape.

Lindstrøm, Bente

1995 Parcelhusgenerationen bryder op - en boligundersøgelse i Skive. Skive: Skive Kommune.

Mennell, Stephen

1985 All Manners of Food: Eating and Taste in England and France from the Middle Ages to the Present. Oxford: Blackwell.

Murcott, Anne

1983 “It's a Pleasure to Cook for Him": Food, Mealtimes and Gender in Some South Wales Households. I: E. Garmarnikow et al. (eds.): The Public and the Private. London:

Heinemann

Møllgaard, Johannes

$1984 \quad$ Byens sociale geografi: Studier af Skive. SBI-Byplanlægning 47.

København: Statens Byggeforskningsinstitut.

Nordic Statistical Secretariat

1995 Yearbook of Nordic Statistics 1995. København: Nordic Council of Ministers.

Power, Anne

1993 Hovels to High Rise: State Housing in Europe Since 1850. London: Routledge.

Reddy, G. Prakash

1993 Danes Are Like That! Perspectives of an Indian Anthropologist on the Danish Society. Mørke: Grevas Forlag.

Redlich, Monica

1939 Danish Delight. London: Duckworth.

Rubow, Cecilie

1993 At sige ordentligt farvel: Om begravelser i Danmark. Frederiksberg: Forlaget ANIS

Sahlins, Marshall

1976 Culture and Practical Reason. Chicago: University of Chicago Press.

Salamon, Karen Lisa Goldschmidt

1992 I grunden er vi enige: En ekskursion i skandinavisk foreningsliv.

Tidsskriftet Antropologi 25:105-16 
Schwartz, Jonathan

1991 Om at dechifrere en dansk frokost. Højskoledebat 116(22):341-5.

Simmel, Georg

1950 The Social and the Individual Level. I: K. H. Wolf (ed.): The Sociology of Georg Simmel. New York: The Free Press.

Skive Kommune

1976 Skive - 650 år. Skive: Skive Kommune.

1994 Statistiske oplysninger om Skive Kommune 1994. Skive: Skive Kommune

Skov- og Naturstyrelsen

1995 Skive Kommuneatlas. København: Miljø- og Energiministeriet, Skov- og Naturstyrelsen.

Trine Kjærhus Sørensen

1997 En skål for vandet. Skive Folkeblad, 15.3.:56.

Tolkien, J. R. R.

1966 The Fellowship of the Ring: Being the First Part of the Lord of the rings. London: George Allen \& Unwin.

Veblen, Thorstein

1924 The Theory of the Leisure Class: An Economic Study of Institutions.

London: George Allen \& Unwin.

Vestergaard, Elisabeth

1995 The Danish Lunch. Informanten: Nyhedsforum for Etnografi 6:9-11. 